\title{
Comparison of Stomatal Density and Postharvest Transpiration between Long- and Short-lived Cut Flower Genotypes of Antirrhinum majus L.
}

\author{
Kenneth R. Schroeder ${ }^{1}$ and Dennis P. Stimart ${ }^{2}$ \\ Department of Horticulture, University of Wisconsin, 1575 Linden Drive, Madison, WI 53706
}

\begin{abstract}
AdDitional INDEX wORDs. snapdragon, postharvest longevity, stomata, stomatal control, stomatal density, stomatal functioning, transpiration, vase life

ABSTRACт. Evaluation of leaf stomatal numbers and postharvest water loss indicate these are important factors in $A n$ tirrhinum majus (snapdragon) cut flower postharvest longevity (PHL). Cut flowers with 9 days longer PHL had $53 \%$ fewer leaf stomata. Long PHL is associated with an early reduction in transpiration followed by low steady transpiration. Short-lived genotypes had a linear transpiration pattern over the period of PHL indicating poor stomatal control of water loss. Short-lived genotypes had $22 \%$ to $33 \%$ reductions in fourth quarter transpiration while long-lived genotypes had $2 \%$ to $8 \%$ reductions. In addition, short-lived genotypes had higher average fourth quarter cut flower weight losses compared to long-lived genotypes. Further investigation of stomatal numbers and functioning relative to PHL may provide breeders a rapid and nondestructive indirect selection method for PHL.
\end{abstract}

Postharvest longevity (PHL) of cut flowers plays a key role in determining cut flower value and consumer acceptance. Acquiring and maintaining acceptable cut flower PHL is an ongoing challenge for the florist industry. Extending PHL involves coordinating conflicting processes of promoting growth and retarding metabolic processes leading to senescence. A portion of PHL can be attributed to pre-harvest conditions of light, temperature, humidity, and nutrition (Celikel and Karacaly, 1995; Halevy and Mayak, 1979; Holley, 1963; Rogers, 1973). At harvest, stem cutting interrupts the natural source of water, carbohydrates and hormones causing premature flower senescence when compared to those nonharvested. Roses on the plant lasted about twice as long as cut roses whether held in preservative solutions or water (Durkin and Kuc, 1966). Noordegraaf (1999) concluded that at harvest, cut flower quality is fixed and beyond that point it decreases. Postharvest longevity of cut flowers is affected by postharvest water relations, carbohydrate status, type of holding solution, hormonal balance and environmental conditions (Borochov and Woodson, 1989; Halevy and Mayak, 1979, 1981; Mayak, 1987; van Doorn, 1997). Postharvest water relations of cut flowers involve a balance between transpiration and water uptake (van Doorn, 1997). Transpiration depends upon temperature, air movement, humidity, stomata, cuticle layers, boundary layers, and solutes in holding solutions (Halevy and Mayak, 1981; van Doorn, 1997). Water uptake depends on composition of holding solution, vascular size, and draw created by relative humidity of surrounding air. Vascular blockage from bacterial growth, physiological factors and development of emboli can limit water uptake (Rogers, 1973; van Doorn, 1999a).

Antirrhinum majus cut flower PHL is quantitatively inherited and influenced by environment (Schroeder and Stimart, 2001). Twenty-five percent or more of observed PHL variability is at-

Received for publication 16 Feb. 2005. Accepted for publication 5 Apr. 2005. Use of trade names does not imply endorsement of the products named or criticism of similar ones not named.

${ }^{1}$ Assistant professor, Kansas State Univ., Dept. of Horticulture, Forestry, and Recreation Resources, Manhattan, KS 66506.

${ }^{2}$ Professor and Chair of Department. To whom reprint requests should be addressed. Email address: dstimart@wisc.edu tributable to floral senescence symptoms. Associations of long PHL with floret browning rather than wilting prompted investigations into physiological explanations for cut flower PHL. The objectives of this study were to investigate cut flower postharvest transpiration and stomatal density of A. majus genotypes in relation to PHL.

\section{Materials and Methods}

Plant Material. Two short-lived inbreds of A. majus with white (WS $=5 \mathrm{~d}$ PHL) and yellow (YS $=6 \mathrm{~d}$ PHL) flowers; a long-lived white $\left(\mathrm{WL}=14 \mathrm{~d}\right.$ PHL) flowered inbred; and $\mathrm{F}_{1}$ hybrids $\mathrm{WS} \times$ WL (9 d PHL) and YS $\times$ WL (11 d PHL) were investigated.

Seeds were germinated and plants grown through flowering in a glasshouse at the Univ. of Wisconsin, Madison, according to established procedures (Ball, 1991; Larson, 1992). Briefly, seeds were germinated in 48 -cell $\left(144 \mathrm{~cm}^{3}\right)$ flats. Seedlings were transplanted into 72 -cell $\left(72 \mathrm{~cm}^{3}\right)$ flats with one plant per cell when the first set of true leaves appeared, and into $11-\mathrm{cm}$-square plastic pots $\left(1100 \mathrm{~cm}^{3}\right)$ when the third to fourth set of true leaves appeared and remained in these pots through flowering. Growing medium was 1 soil : 1 perlite : 1 sphagnum peat (by volume). Plants were spaced on benches on $22-\mathrm{cm}$ centers. They were fertilized biweekly with $200 \mathrm{mg} \cdot \mathrm{L}^{-1}$ of N using Peter's $20 \mathrm{~N}-8.7 \mathrm{P}-16.5 \mathrm{~K}$ water-soluble fertilizer (Scott's Sierra Horticultural Products Co., Marysville, Ohio). Supplemental light from 1000-W high-pressure sodium lamps mounted $183 \mathrm{~cm}$ above the benches $\left(27 \mu \mathrm{mol} \cdot \mathrm{m}^{-2} \cdot \mathrm{s}^{-1}\right)$ was provided daily from 0600 through $2400 \mathrm{HR}$.

Flowering stems were harvested for PHL evaluation when the first five basal florets opened. Stem lengths were adjusted to $40 \mathrm{~cm}$ measuring from the bottom-most floret down. Leaves were removed from the basal $15 \mathrm{~cm}$. Henceforth, these stems are referred to as cut flowers.

Stomatal Density. Cut flowers from the aforementioned five genotypes were harvested 24 July to 6 Aug. 1996. Leaf area per cut flower was determined on leaves removed from five cut flowers per genotype using a LI-3100 area meter (LI-COR, Lincoln, Nebr.). Stoma and epidermal cell counts were made on one leaf 25 $\mathrm{cm}$ below the basal floret on 10 cut flowers per genotype. Excised leaves were pressed abaxial side down for 20 to $30 \mathrm{~s}$ on glass 
microscope slides spread first with a thin layer of cyanoacrylate glue then removed. Slides with impressions were viewed under a light microscope equipped with video imaging. Digital images $550 \times 420 \mu \mathrm{m}$ were photographed and used to count stomata and epidermal cells. One image was taken from each one-third leaf section at basal, middle and apical sites. Cells were counted by aid of a hand held counter while placing dots on cell images using Adobe Photoshop version 5.0 (Adobe Systems, San Jose, Calif.) (Fig. 1). Stomata on the adaxial surface of leaves were not counted since they account for $<3 \%$ of total leaf stomata (Rutland et al., 1987). Average cut flower leaf area for each genotype was multiplied by the respective average stomatal density to determine average number of stomata per cut flower. Stomatal index was calculated using: [number of stomata $\div$ (number of stomata + number of epidermal cells) $] \times 100$. Data were analyzed using the General Linear Models Procedure (SAS Institute, Cary, N.C.). Genotype and leaf section were considered fixed effects.

Postharvest Transpiration-Cut Flowers. Fifteen cut flowers from each genotype were harvested from 10 Apr. through 14 May 1996. Cut flowers were harvested throughout the five-week period as they reached the five-floret stage. Single stems were placed in glass bottles filled with $300 \mathrm{~mL}$ deionized water $\left(\mathrm{dH}_{2} \mathrm{O}\right)$. The open end of the bottle was sealed around the stem with Parafilm (American National Can, Greenwich, Conn.). One hundred milliliters $\mathrm{dH}_{2} \mathrm{O}$ was added to bottles with YS $\times$ WL cut flowers $4 \mathrm{~d}$ postharvest due to low water levels. Weights of the cut flower, and bottle with water, were recorded prior to placing cut flowers into bottles. Bottles with cut flowers were placed on lab benches under continuous cool white fluorescent light $\left(9 \mu \mathrm{mol} \cdot \mathrm{m}^{-2} \cdot \mathrm{s}^{-1}\right)$ at $24^{\circ} \mathrm{C}$ in a completely random design. Weights of cut flowers and bottles plus water were recorded daily to determine fresh weight (FW) change and transpiration. Transpiration was calculated using daily change in water weight minus daily change in cut flower weight divided by time lapsed and expressed as $\mathrm{H}_{2} \mathrm{O}$ loss per gram $\mathrm{FW}$ in milligrams per hour. Cut flowers were discarded when $50 \%$ of open florets wilted or browned.

Due to genotype differences in days of PHL, means for each genotype were divided into quartiles of PHL to compare transpiration and weight change on a quartile basis. A completely randomized design was used, with genotype and quartile considered fixed effects. $\log _{10}$ transformations were used to equalize error variances for transpiration data but not for weight change. Weight change data exhibited some unequal error variance, but variation was random thus, transformation was not suitable. Nontransformed data are presented in figures and tables. Statistical analysis was by the SAS MIXED procedure (Littell et al., 1996) with autoregressive order 1 covariance analysis for repeated measures.

PostharVest TRANSPIRATION-Leaf AREA AND STOMATA. Daily postharvest transpiration was divided by mean genotype cut flower leaf area to get transpiration as $\mathrm{H}_{2} \mathrm{O}$ loss per square centimeter of leaf in micrograms per hour and average number of stomata per cut flower (stomatal density $\times$ leaf area) per genotype to get transpiration as $\mathrm{H}_{2} \mathrm{O}$ loss per stoma in micrograms per hour. Data were analyzed as described above for cut flower transpiration. It is recognized that transpiration is not limited to stomata alone. However, $95 \%$ of water lost by plants is through stomata (Taiz and Zeiger, 1991). Also, water loss may occur through open florets, however, neither rate of floret opening or total number of florets open at discard on A. majus cut flowers appear to be strongly associated with PHL (Schroeder, 2000).

\section{Results and Discussion}

Stomatal Density. Differences in leaf area on cut flowers were not significant across genotypes (Table 1). Measurements ranged from 70 to $109 \mathrm{~cm}^{2}$ with short-lived inbreds (WS and YS) tending to have largest area, the long-lived inbred intermediate and hybrids the smallest area.

Stomatal and epidermal cell densities, stomata per cut flower, and stomatal index were not affected by genotype $\times$ leaf section. Main effects of leaf section and genotype were significant in all cases except leaf section effect on epidermal cell density (Table 2). For leaf section main effect, stomatal density, stomata per cut flower and stomatal index were lower on the basal one-third of a leaf compared to middle and apical sections, which were similar. For genotype main effect, stomatal density, epidermal cell density and stomatal index were not simply related to PHL (Fig. 2A-C). However, within families (WS, WS $\times$ WL, WL and YS, YS $\times$ WL, WL), PHL increased with decreasing stomata per cut flower (Fig. 2D). WL had $53 \%$ and $28 \%$ fewer stomata per

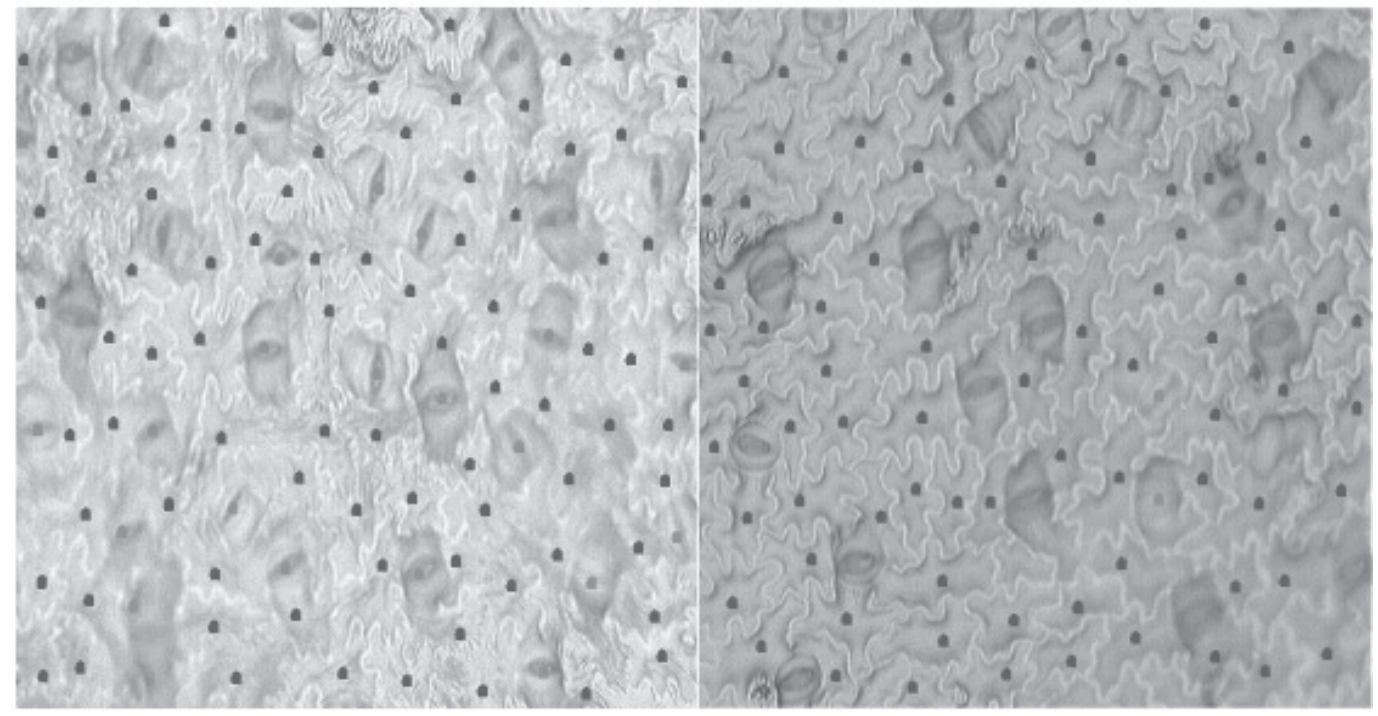

Fig. 1. Digital images $(550 \times 420 \mu \mathrm{m})$ of stomata and epidermal cells on abaxial leaf surface impressions of Antirrhinum majus cut flower inbreds white short-lived =WS (left) and white long-lived = WL (right) 5 and 14 d postharvest longevity, respectively. Dots mark cells counted. 
Table 1. Means and analysis of variance for Antirrhinum majus cut flower leaf area as influenced by genotype.

\begin{tabular}{lcc}
\hline Genotype & Leaf area $\left(\mathrm{cm}^{2}\right)^{\mathrm{z}}$ & \\
\hline WS & 107.1 & \\
YS & 108.7 & \\
WS x WL & 70.0 & \\
YS x WL & 102.7 & Mean squares \\
WL & 103.0 & $1287.2^{\mathrm{NS}}$ \\
\hline Source of variation & df & 668.1 \\
\hline Genotype & 4 & \\
Error & 20 & \\
\hline
\end{tabular}

${ }^{2}$ Total leaf area from bottom floret to $25 \mathrm{~cm}$ down.

Ns Nonsignificant at $P \leq 0.05$.

cut flower than WS and YS, respectively. Postharvest longevity increased $9 \mathrm{~d}$ when stomata per cut flower decreased $53 \%$. Hybrids did not differ from each other and were intermediate between respective parents.

De Gelder (1989) points out that different reasons for termination of vase life can be an undesirable source of variation when evaluating PHL. Interestingly, in our studies, if YS was misclas- sified due to discarding because of rapid yellow color degradation instead of wilting or drying of tissue as with the white lines, the final interpretation would change. If for example, discoloration of yellow (YS) flowers was ignored in our studies and PHL subsequently increased by 4 to $5 \mathrm{~d}$, then stomatal density and stomatal index would show a negative relationship with PHL (Fig. $2 \mathrm{~A}$ and $\mathrm{C}$ ). This would then allow stomatal density to be used as a nondestructive method of indirect selection for long $A$. majus PHL. However, further analysis needs to be done to test this possibility.

Transpiration. Postharvest transpiration based on grams FW, square centimeters of leaf area, and stoma were affected significantly by genotype, quartile, and genotype $\times$ quartile (Table $3)$. Early reduction in transpiration and establishment of a low steady transpiration for the last three-fourths of postharvest life appear key to long PHL (Fig. 3 A and B). Percent reduction of water transpired from quartile one to two exhibited a positive relationship with PHL. Specifically, transpiration per gram FW decreased by $23 \%, 39 \%, 61 \%, 65 \%$, and $66 \%$ and per square centimeter of leaf area and by $17 \%, 34 \%, 57 \%, 60 \%$, and $63 \%$ for WS $(5 \mathrm{~d}$ PHL), YS (6), WS $\times$ WL (9), YS $\times$ WL (11), and WL (14), respectively, in quartile two compared to quartile one. At the middle of PHL, transpiration and PHL showed an inverse

Table 2. Analysis of variance for stomatal and epidermal cell density, stomata per cut flower and stomatal index on Antirrhinum majus abaxial leaf surfaces as influenced by genotype and leaf section.

\begin{tabular}{|c|c|c|c|c|c|}
\hline \multirow{3}{*}{$\begin{array}{l}\text { Source of } \\
\text { variation }\end{array}$} & \multirow{3}{*}{$\mathrm{df}$} & \multicolumn{4}{|c|}{ Mean squares } \\
\hline & & \multirow{2}{*}{$\begin{array}{l}\text { Stomata per } \\
\text { cut flower }\end{array}$} & \multicolumn{2}{|c|}{ Density } & \multirow{2}{*}{$\begin{array}{l}\text { Stomatal } \\
\text { index }^{z}\end{array}$} \\
\hline & & & Stomatal & Epidermal cell & \\
\hline Genotype $^{\mathrm{y}}(\mathrm{G})$ & 4 & $69,068.0^{* * * *}$ & $543.0^{* * * *}$ & $540.0^{* * * *}$ & $619.8^{* * * *}$ \\
\hline Section $^{x}(S)$ & 2 & $3,535.9^{* *}$ & $43.1^{* * *}$ & $22.4^{\mathrm{NS}}$ & $78.2^{*}$ \\
\hline $\mathrm{G} \times \mathrm{S}$ & 8 & $838.7^{\mathrm{NS}}$ & $10.2^{\mathrm{NS}}$ & $14.8^{\mathrm{NS}}$ & $10.8^{\mathrm{NS}}$ \\
\hline Error & 135 & 503.2 & 5.5 & 23.3 & 19.6 \\
\hline
\end{tabular}

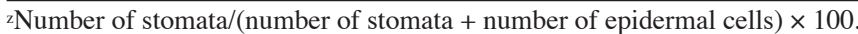

yInbreds white short-lived (WS), yellow short-lived (YS) and white long-lived (WL); and $\mathrm{F}_{1}$ hybrids WS $\times$ WL and YS $\times$ WL.

xBasal, middle and apical leaf section.

Ns, $, * *, * * * * * * * *$ Nonsignificant or significant at $P \leq 0.05,0.01,0.001$, or 0.0001 , respectively.
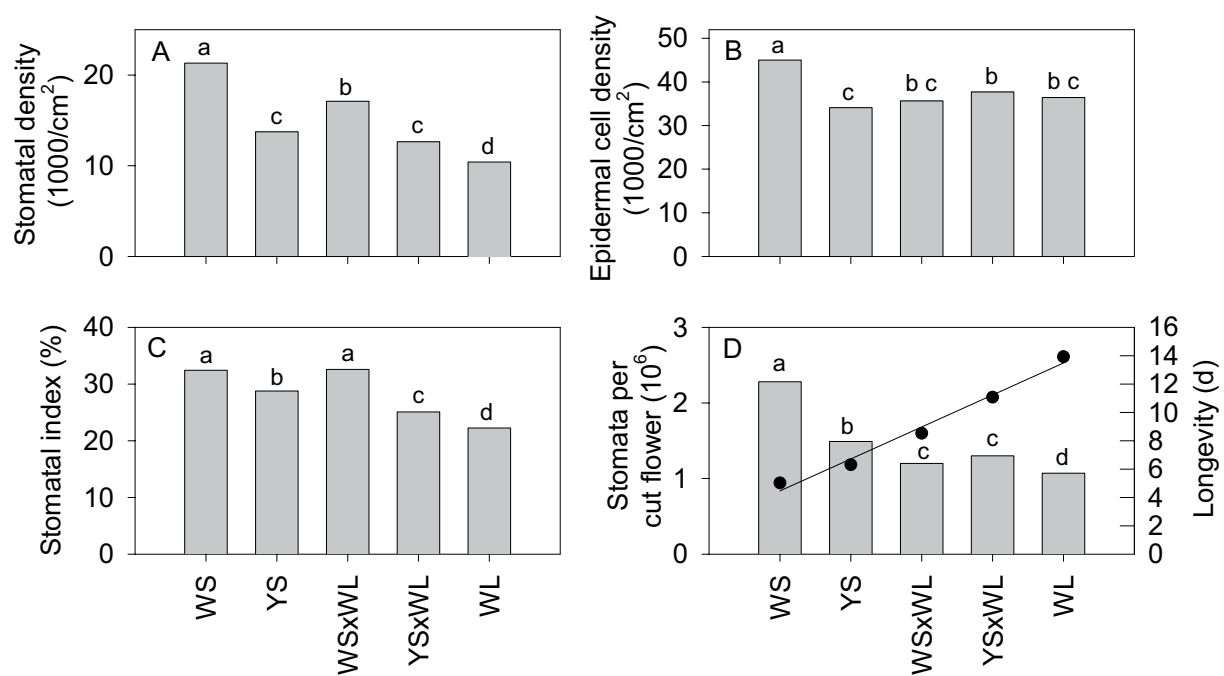

\section{Genotype}

Fig. 2. Antirrhinum majus cut flower stomatal density (A), epidermal cell density (B), stomatal index [number of stomata $\div$ (number of stomata + number of epidermal cells $) \times 100](\mathbf{C})$, and stomata (bar graph) and postharvest longevity (line graph) $(\mathbf{D})$ as influenced by genotype. Inbreds white short-lived $=$ WS, yellow short-lived $=\mathrm{YS}$, white long-lived $=\mathrm{WL}$, and $\mathrm{F}_{1}$ hybrids $\mathrm{WS} \times \mathrm{WL}$ and $\mathrm{YS} \times \mathrm{WL}$. Genotypes arranged from shortest to longest postharvest longevity from left to right. Mean separation by $\operatorname{LSD}_{0.05}$. 
Table 3. Likelihood estimates for rate of postharvest transpiration based on cut flower fresh weight, average leaf area and stoma; and fresh weight change on Antirrhinum majus cut flowers as influenced by genotype and quartile of postharvest life.

\begin{tabular}{|c|c|c|c|c|c|}
\hline \multirow[b]{3}{*}{$\begin{array}{l}\text { Source of } \\
\text { variation }\end{array}$} & \multirow[b]{3}{*}{ df } & \multicolumn{4}{|c|}{ F-value } \\
\hline & & \multicolumn{3}{|c|}{ Transpiration $^{\mathrm{z}}$} & \multirow{2}{*}{$\begin{array}{c}\text { Weight change } \\
\left(\mathrm{mg} \cdot \mathrm{h}^{-1}\right)\end{array}$} \\
\hline & & $\begin{array}{l}\text { Perg FW } \\
\left(\mathrm{mg} \bullet \mathrm{h}^{-1}\right)\end{array}$ & $\begin{array}{c}\text { Per } \mathrm{cm}^{2} \text { of leaf } \\
\left(\mu \mathrm{g} \cdot \mathrm{h}^{-1}\right)\end{array}$ & $\begin{array}{r}\text { Per stoma } \\
\left(\mu \mathrm{g} \bullet \mathrm{h}^{-1}\right)\end{array}$ & \\
\hline Genotype $^{\mathrm{y}}(\mathrm{G})$ & 4 & $30.43^{* * * *}$ & $35.19^{* * * *}$ & $6.24^{* * *}$ & $6.58^{* * * *}$ \\
\hline Quartile (Q) & 3 & $1002.29^{* * * *}$ & $823.38^{* * * *}$ & $254.65^{* * * *}$ & $460.23^{* * * *}$ \\
\hline \multirow[t]{2}{*}{ Gx Q } & 12 & $34.97^{* * * *}$ & $35.57^{* * * *}$ & $15.83^{* * * *}$ & $9.91^{* * * *}$ \\
\hline & & \multicolumn{4}{|c|}{ Variance estimates } \\
\hline $\operatorname{AR}(1)^{x}$ & & $0.5947^{* * * *}$ & $0.8103^{* * * *}$ & $0.5673^{* * * *}$ & $0.0049^{\mathrm{NS}}$ \\
\hline Residual & & 0.0065 & 0.0128 & 0.0295 & 0.0005 \\
\hline
\end{tabular}

zAnalysis on $\log _{10}$ transformed data.

yInbreds white short-lived (WS), yellow short-lived (YS), and white long-lived (WL); and $\mathrm{F}_{1}$ hybrids WS $\times$ WL and YS $\times$ WL.

${ }^{x}$ Autoregressive order 1 covariance analysis for repeated measures.

NS, ${ }^{* * *, * * * *}$ Nonsignificant or significant at $P \leq 0.001$ or 0.0001 .

relationship (Fig. 3A). WL transpired least, hybrids intermediate, and YS and WS the most. Note, WS $\times$ WL transpired at a higher rate than YS $\times$ WL in quartiles two and three, however, in quartile four they switched rank. Similarly, greater reduction in transpiration per stoma and steady transpiration in quartiles three and four relate to long PHL (Fig. 3C). All genotypes exhibited decreased transpiration during quartile four compared to three. However, the short-lived genotypes (WS, YS, and WS $\times$ WL) had a larger decrease compared to the long-lived genotypes (Fig. $3 \mathrm{~A}-\mathrm{C})$. The hybrids having similar numbers of stomata per cut flower (Fig. 2D) exhibited similar transpiration patterns until quartile four (Fig. 3C) when WS $\times$ WL (9 d PHL) showed a 37\% reduction in transpiration compared to quartile three while YS $\times$ WL $(11 \mathrm{~d}$ PHL) reduction was $14 \%$. This greater transpiration reduction of WS $\times$ WL compared to YS $\times$ WL coincides with 2 $\mathrm{d}$ less PHL.

Short-lived inbreds seem to lack stomatal control of water loss as indicated by linear transpiration patterns (Fig. 3A-C). On intact A. majus, McDaniel and Miller (1976) demonstrated that low transpiration during flowering caused by stomatal closure produced the best quality cut flowers. Similarly, a negative relationship between flower stem quality and stomatal transpiration of intact plants of A. majus 'Oklahoma' and 'Panama' was reported by Rutland et al. (1987). High transpiration is expected with open stomata and a reduction upon closure (van Doorn, 1997). Variation in stomatal functioning was found to affect PHL of Rosa xhybrida L. cut flowers (Mayak et al., 1974; Mortensen and Fjeld, 1995).

Endogenous abscisic acid (ABA) levels or sensitivity to ABA may be affecting A. majus stomatal functioning. Abscisic acid causes stomatal closure in many plants (Asamaa et. al., 2002; Correia et. al., 1997; Liu et. al., 2001). In Hordeum vulgare L., stomatal conductance decreased in response to increased ABA in xylem sap and response varied among lines (Borel et al., 1997). Further study is needed in this area to determine if endogenous ABA levels and stomatal functioning vary among long- and short-lived A. majus genotypes.

For main effect quartile, transpiration decreased significantly when compared to respective previous quartiles. Largest reduction in transpiration was between quartile one and two. For main effect of genotype, PHL did not show a direct relationship to transpiration.

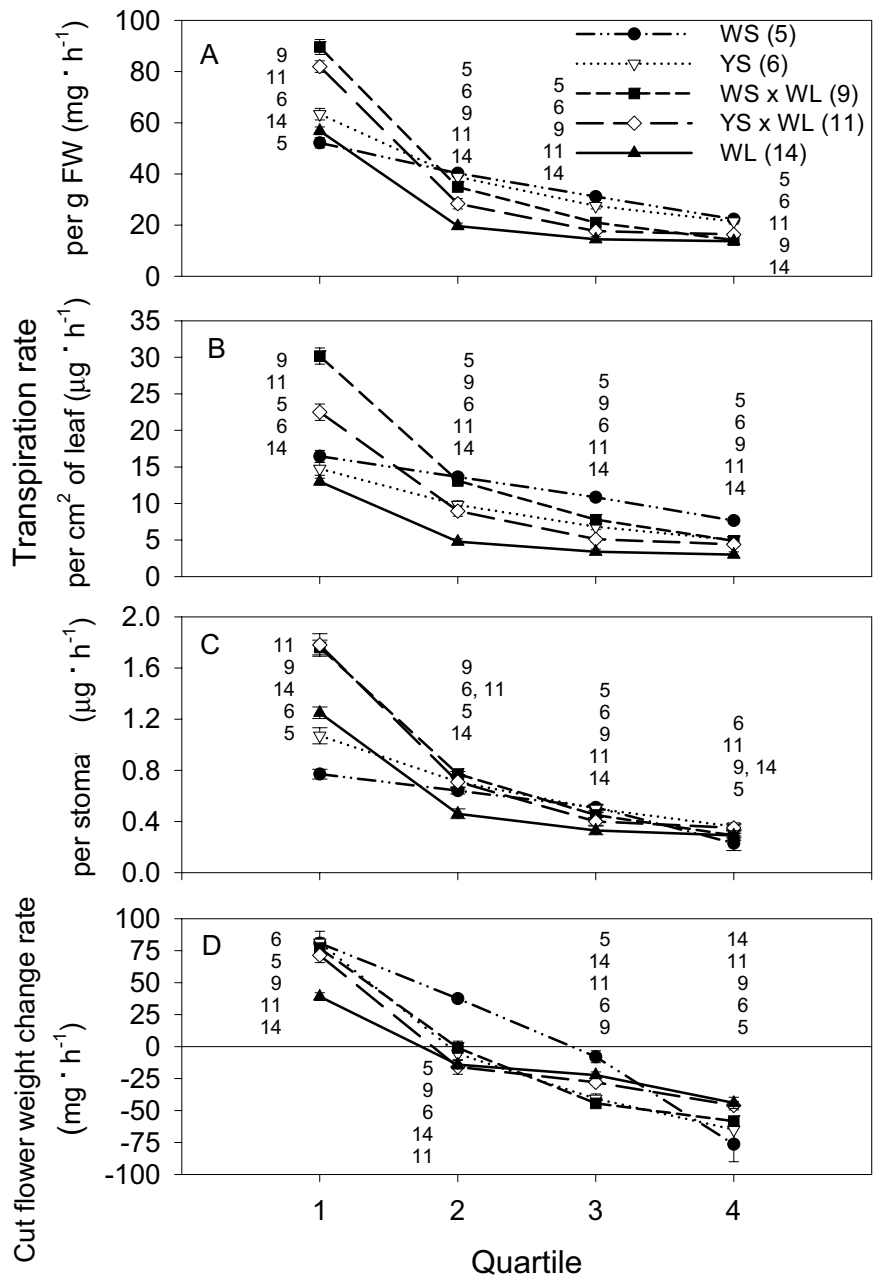

Fig. 3. Postharvest transpiration rate per gram of fresh weight (A), $\mathrm{cm}^{2}$ of leaf (B), and stoma (C), and rate of fresh weight change postharvest (D) of Antirrhinum majus cut flowers as influenced by genotype $\times$ quartile. Inbreds white short-lived $=\mathrm{WS}$, yellow short-lived $=\mathrm{YS}$ and white long-lived $=\mathrm{WL}$, and $\mathrm{F}_{1}$ hybrids $\mathrm{WS}$ $\times W L$ and YS $\times$ WL. Values in parenthesis are days of postharvest longevity (PHL). Vertical bars represent \pm SE. Numerical columns represent PHL rankings within quartile. 
Cut flower weight change. A significant genotype $\times$ quartile interaction influenced cut flower weight change (Table 3 ). The main effects of quartile and genotype were significant but did not show a direct relationship to PHL.

Long PHL appears to be associated with lower average weight loss during the last one-half of postharvest life (Fig. 3D). During quartile four, fresh weight change and PHL showed a negative relationship, with shorter PHL genotypes exhibiting greater weight loss (Fig. 3D). This loss is probably from higher transpiration rates than water uptake thus enhancing senescence (Mayak, 1987; Rogers, 1973; van Doorn, 1997). This may indicate development of vascular occlusions in the short-lived genotypes, which concurs with reports by van Doorn $(1997,1999$ a) that vascular occlusions are a main factor limiting cut flower longevity. Van Doorn (1999b) concluded that early wilting and concurrent premature senescence of cut flowers depends in part on the degree of vascular blockage and rate of transpiration. In roses of the same variety that differ in transpiration, those with highest transpiration show symptoms of vascular occlusions earlier leading to premature senescence from water stress (Noordegraaf, 1999). It is interesting to note, in our study both WS and WS $\times$ WL exhibited substantial decreases in stomatal transpiration from quartile three to four $(56 \%$ and $37 \%$, respectively, Fig. 3C) indicating a possible genetic component. Studies need to be done to determine if genotype differences exist for vascular occlusions or if genetic association results from differences in stomatal numbers alone.

In conclusion, low number of stomata per cut flower, low stomatal transpiration, and stomatal control of water loss are major factors determining A. majus cut flower PHL. Further investigation into genetics and heritability of stomatal numbers on A. majus is warranted. The methods for analysis are relatively simple and if correlated with cut flower PHL could provide breeders a rapid nondestructive indirect selection method for extending PHL. In addition to studying stomatal density on mature leaves, it would be beneficial to determine correlations of stomatal density on juvenile leaves with those of mature leaves. This could provide an early screen for long PHL segregating in a breeding population

\section{Literature Cited}

Aasamaa, K., A. Sober, W. Hartung, and U. Niinemets. 2002. Rate of stomatal opening, shoot hydraulic conductance and photosynthetic characteristics in relation to leaf abscisic acid concentration in six temperate deciduous trees. Tree Physiol. 22:267-276.

Ball, V. 1991. Ball redbook. 15th ed. Ball Publishing, Batavia, Ill.

Borel, C., T. Simonneau, D. This, and F. Tardieu. 1997. Stomatal conductance and ABA concentration in the xylem sap of barley lines of contrasting genetic origins. Aust. J. Plant Physiol. 24:607-615.

Borochov, A. and W.R. Woodson. 1989. Physiology and biochemistry of flower petal senescence. Hort. Rev. 11:15-43.
Celikel, F.G. and Y. Karacaly. 1995. Effect of preharvest factors on flower quality and longevity of cut carnations (Dianthus caryophyllus L.). Acta Hort. 405:156-163.

Correia, M.J., M.L. Rodrigues, M.I. Ferreira, and J.S. Pereira. 1997. Diurnal change in the relationship between stomatal conductance and abscisic acid in the xylem sap of field-grown peach trees. J. Expt. Bot. 48:1727-1736.

De Gelder, I.A. 1989. Components of keeping quality used in variety evaluation. Acta Hort. 261:233-240.

Durkin, D. and R. Kuc. 1966. Vascular blockage and senescence of cut rose flowers. Proc. Amer. Soc. Hort. Sci. 89:683-688.

Halevy, A.H. and S. Mayak. 1979. Senescence and postharvest physiology of cut flowers, Part 1. Hort. Rev. 1:204-236.

Halevy, A.H. and S. Mayak. 1981. Senescence and postharvest physiology of cut flowers, Part 2. Hort. Rev. 3:59-143.

Holley, W.D. 1963. Growing keeping quality into your flowers, p. 9-18. In: M.N. Rogers (ed.). Living flowers that last. Univ. of Missouri, Columbia.

Larson, R.A. 1992. Floriculture. 2nd ed. Academic, San Diego.

Liu, L., A.J.S. McDonald, I. Stadenberg, and W.J. Davies. 2001. Abscisic acid in leaves and roots of willow: significance for stomatal conductance. Tree Physiol. 21:759-764.

Littell, R.C., G.A. Milliken, W.W. Stroup, and R.D. Wolfinger. 1996. SAS system for mixed models. SAS Inst., Cary, N.C.

Mayak, S. 1987. Senescence of cut flowers. HortScience 22:863-865. Mayak, S., A.H. Halevy, S. Sagie, A. Bar-Yosef, and R. Bravdo. 1974. The water balance of cut rose flowers. Physiol. Plant. 32:15-22.

McDaniel, G.L. and M.G. Miller. 1976. Transpiration of snapdragon under southern summer greenhouse conditions. HortScience 11:366-368.

Mortensen, L.M. and T. Fjeld. 1995. High air humidity reduces the keeping quality of cut roses. Acta Hort. 405:148-155.

Noordegraaf, C.V. 1999. Problems of postharvest management in cut flowers. Acta Hort. 482:53-58.

Rogers, M.N. 1973. An historical and critical review of postharvest physiology research on cut flowers. HortScience 8:189-194.

Rutland, R.B., H.L. Chang, and J.E. Pallas, Jr. 1987. Stomatal density of snapdragon as a possible determinant of transpiration. HortScience 22:599-601.

SAS Institute. 1990. SAS/STAT user's guide. Ver. 6.09. 44th ed. vol.2. SAS Inst., Cary, N.C.

Schroeder, K.R. 2000. A study on the genetics and physiology of Antirrhinum majus L. cut flower postharvest physiology. PhD Diss., Univ. of Wisconsin-Madison, Madison, Wis.

Schroeder, K.R. and D.P. Stimart. 2001. Genetic analysis of cut-flower longevity in Antirrhinum majus. J. Amer. Soc. Hort. Sci. 126:200-204.

Taiz, L. and E. Zeiger. 1991. Plant physiology. Benjamin/Coming, Redwood City, Calif.

van Doorn, W.G. 1997. Water relations of cut flowers. Hort. Rev. 18:1-85.

van Doorn, W.G. 1999a. Vascular occlusion in cut flowers. I. General principles and recent advances. Acta Hort. 482:59-63.

van Doorn, W.G. 1999b. Water relations of cut flowers. II. Some species of tropical provenance. Acta Hort. 482:65-69. 